\title{
Redesigning the Welfare Contract in Theory and Practice: Just What Is Going on in the USA?
}

\author{
ALEX WADDAN* \\ * Lecturer in Politics, School of Humanities and Social Science, University of Sunderland, \\ Priestman Building, Green Terrace, Sunderland SR1 3PZ
}

\begin{abstract}
The Personal Responsibility and Work Opportunity Act of 1996 was a landmark in American social policy. There were a number of objectives, but the primary purpose was to end the Aid to Families with Dependent Children programme which was a cash benefit paid to poor, very largely single-parent, families. The underlying theme was that AFDC had constituted a 'something for nothing' programme which had violated the primacy of work. The Act acknowledged that government had an initial duty to aid those falling on hard times, but also stated that there comes a time when government's obligation diminishes. This legislation has generated much interest in the UK, but there is a danger of important elements of the American story being overlooked. In order to understand, therefore, just what is going on this paper looks at the US welfare-to-work experiment on its own terms. The article looks at the movement behind reform and at why, despite evidence of increased hardship for some, five years on from passage the conventional wisdom is that PRWORA has been a success.
\end{abstract}

\section{Introduction}

In August 1996 the USA embarked on a radical welfare to work experiment aimed at working-aged adults receiving means-tested income benefits. ${ }^{1}$ This generated much interest in the UK and informed analysts have drawn attention to the manner in which British policy appears to have been influenced by developments in America (King and Wickham-Jones, 1999; Deacon, 2000). Both countries have seen an emphasis on moving welfare recipients into work, and a willingness to implement coercive measures in order to enforce this movement. There were also parallel political motives at work in the two countries as New Democrat and New Labour leaders chose welfare reform as an area where they could establish their 'New' credentials by asserting a more dynamic relationship between the state and the welfare recipient. That is, whereas old Democrats and old Labour were perceived as soft on welfare, the 'New' variety were to be tough in their dealings with indolent claimants. Indeed the repudiation of the idea that there are unqualified claims which able-bodied, working-aged, adults can make against 
the state has been quite categorical, embodied in the language which declares 'no rights without responsibilities', effectively disavowing any notion of welfare entitlement or 'social rights'. ${ }^{2}$

Despite the similarities, however, it is important to understand what is happening in the USA on its own terms. While welfare is an important social and political issue in the UK it does not have the heightened symbolic significance that is apparent in the USA. That is, while popular understanding of the complexities of the American welfare system might be limited, welfare as an issue encapsulates a clash of values about the importance of work in American life; and what was particularly at issue in the mid-1990s was the position of long-term welfare dependants and the sense that they had neglected their duties and had thus forfeited full citizenship status. According to Judith Shklar, while the collection of American attitudes towards welfare is not perhaps a coherent ideology ... it is certainly an intelligible one. Not to work is not to earn, and without one's earnings one is "nobody" (1991: 92). Weaver et al. summarised their study of opinion polls asking about attitudes towards welfare thus:

Welfare has come to connote dependence ... and ... is perceived to have greater negative than positive effects ... majorities of the public are concerned that welfare benefits may be too high and that welfare encourages long-term dependence, and that too many welfare recipients do not want to work ... 'Welfare', in short, is perceived as being at odds with the widely shared American values of individualism and the work ethic. (1995: 607)

One poll in October 1994 showed that 89 per cent of respondents favoured a two-year welfare limit followed by work and 76 per cent agreed that having another child while on welfare should not result in extra benefit. Reflecting on these results, Urban Institute analyst Isabel Sawhill offered the following explanation for why policymakers were increasingly advocating experimental programmes which were not based on rigorous social science research:

[I]t is because research gives insufficient emphasis to the role of public morality ... It ignores the public's desire to align welfare rules with their own values. The public is not lacking in compassion, but it does believe that poor people should play by the same rules as the middle class. When you don't work, you don't get paid. And when you have another baby, you don't get a raise. (1995: 8)

In short, by the 1990 s many Americans, including many policymakers, had concluded that too many welfare recipients were not making a serious work effort. Thus Clinton's 1992 campaign promise 'to end welfare as we know it'. As it was, the changes enacted in 1996 were more dramatic than Clinton had envisaged; but the fact that he signed the Republican Congress's reform bill illustrates how welfare was perceived to be a potential wedge issue which could cost him serious votes in the upcoming presidential election. 


\section{The reform}

Without doubt the Personal Responsibility and Work Opportunity Reconciliation Act was a landmark in American social policy. It was, in the words of the Green Book, the bible of US social policy data, 'the first time that major welfare entitlement benefits have been repealed or substantially altered' (US, 1996: 1328). The PRWORA had a number of objectives, but its primary purpose was to end the Aid to Families with Dependent Children (AFDC) programme which had been part of the 1935 Social Security Act. In 1994, when AFDC rolls were at their peak, it provided benefits to a monthly average of just over 5 million families, adding up to just over 14.2 million recipients - constituting 14.8 per cent of American families with children under eighteen. The total cost was $\$ 23.4$ billion of which the federal government paid just over half and the state governments the remainder. The average monthly benefit per family was $\$ 386$ (US, 1996: 386 ), although this figure hides large discrepancies between states which set their own level of benefit.

Critical to understanding the gravity of the changes enacted is that AFDC was a programme which directed income support to poor, largely single parent, households with children under eighteen. ${ }^{3}$ Thus the new law explicitly targeted low-income female headed families with the purpose of shifting them off welfare, preferably by getting the mothers into work or into a stable relationship with another wage earner. The underlying theme was that AFDC had constituted a 'something for nothing' programme which had undermined traditional American principles about the value of work and which, in doing so, had simultaneously created resentment among the majority, non-welfare, population and demeaned those on welfare by entrapping them in a cycle of dependency. For social conservatives this self-defeating behaviour was highlighted by the rise in out-of-wedlock births, and for some the goal of PRWORA was as much to resurrect the primacy of marriage and the two-parent family as it was to require work (Deacon, 2001: 4-9).

One of the key features of PRWORA was the devolution of responsibility for drawing up particular welfare to work programmes down to the states. ${ }^{4}$ The money which the federal government had previously spent on AFDC was given to the states with no specific directives about how rolls should be reduced or work encouraged. On the other hand, this devolution came with considerable strings attached for the states in terms of how future federal money was tied to reaching work participation requirements and/or caseload reduction targets. More fundamentally, the law set absolute time limits for how long welfare recipients could be paid benefits with federal money. ${ }^{5}$

In brief, the PRWORA replaced AFDC with a benefit named Temporary Assistance to Needy Families. The law stipulated that welfare recipients could receive TANF cash benefits for a maximum of two years before being required to engage in some sort of work-related activity, a time frame which can be shortened at state discretion. The law does allow that claimants can be engaged 
in government sponsored activities such as education, training or subsidised employment, at state discretion, for a further three years but this marks the end of their assistance, and this five-year limit is a lifetime limit on the receipt of TANF benefits (and again this five-year limit is a maximum which can be shortened at state discretion). Overall, although the Act acknowledges that government has an initial duty to provide aid to those falling on hard times, it states that there does come a time when government no longer has an obligation to help those deemed not to be making a sufficient effort to help themselves and even, theoretically, those making a good faith effort to play by the rules but who do not have the resources to make it on their own. Furthermore, while in receipt of benefits claimants will suffer financial sanctions if they do not comply with state rules about work effort. The regulations about and use of sanctions as an arm of policy vary considerably from state to state but all programmes utilise them in one form or another.

In reality, given the composition of the welfare population, these new work requirements meant that single mothers with children under eighteen were now presumed to be self-sufficient in the long term. Furthermore, this supposition applied to all able-bodied welfare mothers, however complex their domestic circumstances and however limited their educational qualifications or prior work experience. States can, however, exempt 20 per cent of their caseload from the five-year lifetime limit which gives some leeway to cater for those who have become known as 'hard to employ' recipients (see US: 2001). ${ }^{6}$

\section{The attack on AFDC}

Inherent in US social policy is a suspicion of giving income benefits to those of working age and this distrust was apparent even at the establishment of AFDC (then ADC) in 1935. ADC was always a secondary programme in relation to the main contributory based social insurance old age and unemployment schemes set up for wage earners. ADC, for example, was one of only two benefits (along with Aid to the Blind) established by the 1935 Act which included a criteria of need. Furthermore, the benefit was intended only for single mothers who were deemed to be morally worthy - assumed to be widows and some deserted mothers which left claimants subject to investigation with their fate in the hands of local caseworkers: and even if a mother satisfied the criteria of being both worthy and poor the benefit level still reflected an ambivalence about substituting cash benefits for work. Thus, although the stated intention was to allow women to play the role of mother rather than worker, the payments were often so low that the women could only survive by supplementing their benefit through working (Gordon, 1994: 294-301).

Nevertheless, by the late 1960 s AFDC had attained something approaching entitlement status for poor single-parent families, especially after a series of 
Supreme Court decisions in the 1960 s took away much of the discretion exercised at local level about eligibility (Teles, 1996:107-17).7 These changes and the growing number of single-parent families did lead to a significant jump in the number of families enrolled on AFDC. In 1960, the average monthly number of families receiving AFDC was 803,000, which jumped to just over 1.9 million by 1970 (US, 1998: 402). One consequence was that from 1969 "welfare reform" became a persistent refrain in American politics.

Throughout the 1970s various unsuccessful reform efforts contained both liberal and conservative strands (Waddan, 1998), but from the early 1980s the rhetoric took on a more distinctly conservative trajectory as Reagan railed against welfare dependency and invoked the stereotype image of the 'welfare queen'. Reagan's rhetorical bombast was matched by the work of Charles Murray and George Gilder (Gilder, 1981; Murray, 1984). Their arguments were continued through the 1990 s by Robert Rector of the influential right-wing think tank, the Heritage Foundation (Rector, 1992; 1996). The primary contention of these writers is well versed and not that complex. In short, the expansion of welfare programmes, however well-intentioned, was a social disaster as it simply encouraged people to make choices which in the long term deprived them of their dignity and their capacity to make a meaningful contribution to society. This in turn detached them from society and created a quasi-permanent underclass trapped into a culture of dependency. The necessary response was to end those programmes which fuelled this deviant behaviour.

While Murray and Rector provided the most dramatic expression of anti-welfare sentiment a subtler line of conservative thought also emerged, championed most articulately by Lawrence Mead. What makes Mead particularly interesting is his willingness to tackle the question of social rights as posed by Marshall. While Murray and Rector simply do not accept that able-bodied adults have legitimate claims against the state, Mead does not call for the withdrawal of government; indeed his 'new paternalism' proposes measures which are highly interventionist (1997a). His contention, however, is that the social conditions which provided a powerful de facto rationale for entitlement welfare have changed. When contemplating the 'duty of the individual not to become destitute, if he can help it', Marshall reflected, 'In conditions of full employment and a rising standard of living the temptation to indulge in voluntary penury has lost any force it ever had, and, though difficult cases may still sometimes arise, the problem is not one of real importance' (1981: 90). According to Mead, while this may have been true in the immediate postwar period, by the late $1960 \mathrm{~s}$ the declining work effort of the welfare poor demanded a change of policy emphasis:

Before 1960, poverty levels were much higher than now, but most poor adults were employed, and this tended over time to integrate them. Today, there is less poverty, but 
the separation of the poor from the economy makes integration more doubtful. Therefore, social programs must promote work, and even enforce it, assuming the function that the workplace did before. (1997b: 229)

Mead's examination of the work levels of the non-poor and the welfare poor led him to conclude, 'High work levels for the general population sustain the citizenship rationale for the social insurance welfare state, but low work levels for the poor put that case in question for welfare and other antipoverty programs' (p. 206). That is, the non-working poor must abide by society's norms to lay claim to the 'social rights' of citizenship. These norms include the willingness to work, even for low wages in undesirable jobs; but, according to Mead, too many of the welfare poor had shirked this obligation by not taking jobs which were available and which they could do (1997c: 6-31).

Another key contributor to this discourse was David Ellwood, whose seminal book, Poor Support, recommended a clear time limit to welfare receipt (1988). The book also discussed how government could provide a whole array of support services, including acting as an employer of last resort and making work a significantly more attractive financial option for welfare recipients; it was, however, the concept of time limits coming from someone regarded as a moderate Democrat which made his analysis politically compelling. Furthermore, the general tirades against dependency had more credibility after surveys during the 1980s illustrated that a greater proportion of welfare recipients were longterm clients than had previously been understood. The traditional methods of data collection suggested that, while there was a lot of cycling on and off welfare, most welfare spells were relatively short lived. Analysis, however, which did not look at the total number of welfare spells but at the welfare population at a given point in time showed that about half the recipients were in spells which would last eight years and more (Bane and Ellwood, 1994). This gave support to those who insisted that there was a chronic problem of long-term welfare dependence. Another critical change to the terms of the debate was the increase in female participation in the labour force. The traditional perception of the mother's role as being one of nurturing her young was thus a less persuasive argument for not demanding work of welfare mothers.

Prior to PRWORA the most recent welfare reform measure enacted at federal level was the 1988 Family Support Act. This gave a more formal structure to existing work requirements, but also instituted some supportive services. Advocates championed it as embracing a potentially productive carrot and stick approach. The directives of the Act, however, were to be applied gradually and before the changes had a chance to make a mark the reform was overtaken by events as the welfare rolls grew rapidly. AFDC numbers had been relatively stable through the 1980 os but between 1988 and 1992 the number of recipients rose from 10.9 million to 13.6 million (US 1994: 325 ). Thus welfare was once again in the 
news in 1992. When Governor of Arkansas, Clinton had been heavily involved in the development of the FSA, illustrating his genuine interest in and knowledge of welfare issues. On the other hand, his 1992 campaign rhetoric exploited welfare to emphasise his 'different kind of Democrat' outlook. The details of prospective reform were not fleshed out, but the dramatic language used created a hostage to fortune.

The administration did put forward a plan of its own in the summer of 1994 which extended the FSA's principles of combining compulsion with support. What was new, though, was the inclusion of an explicit two-year time limit before a work requirement kicked in. The proposal did also, however, acknowledge a role for government as an employer of last resort, and allowed those who left welfare to move into work to buy back future welfare time. ${ }^{8}$ The bill made no legislative headway, however, and the Republican success in November 1994 further shifted the dynamic of the welfare debate. PRWORA firmly declared that no able-bodied, working-aged adult is entitled to cash assistance from the state either for herself or her children for more than a minimal period. The political question was whether Clinton would sign this into law. His key welfare advisers, who had worked on the administration's own proposal, urged him to veto the bill, but to no avail (Ellwood, 1996; Bane, 1997; for the story of the final passage of PRWORA see Weaver, 2000: 317-55).

\section{Assessing reform: more than Wisconsin}

Over five years on, the prevailing wisdom is that the reform has been a success although critics still identify causes for concern. There has been a dramatic decline in welfare caseloads and an increased work effort by former recipients. On the other hand, there is little evidence that those working are significantly better off and there are signs of increased hardship for some. Before examining the evidence, however, it is important to note the methodological problems inhibiting assessment. Primarily, there is just too much going on for the reform process to be regarded as a controlled experiment. For example, the extended period of economic prosperity during the 1990s meant wider job availability which might explain the decline in the welfare rolls without reference to PRWORA, especially when coupled with enhanced work incentives in the form of the increased minimum wage and the expanded Earned Income Tax Credit. Advocates of reform, however, insist that previous periods of prosperity had not seen a decline in the welfare rolls comparable to that which followed the enactment of PRWORA. There are also problems in the collection and analysis of data. For example, how should work participation be calculated? Should surveys count those who have moved into work but then returned to welfare? And should workforce participation be calculated on a 'point in time' basis or should it include anyone who has worked at all over a certain duration? 
Such problems are familiar ones to social science research, but the complexities are exacerbated when trying to appraise developments across the fifty states. Although the PRWORA was very prescriptive in a number of ways it also left the states with a variety of options. In a recent paper looking at workfare policy in the USA and its adaptation in the UK, Deacon reflects on some important differences between the two countries (2000). One point he makes is that many British observers have only a limited understanding of the nature of American federalism and how this has impacted on welfare reform. He comments that the British social policy analyst's mental map of the USA has New York and California separated by the vast continent of Wisconsin (p. 7); unfortunately, the sharpness of this line almost conceals its significant truth.

The Wisconsin story is important because it has combined coercion and support in a vigorous fashion; the state's welfare rolls dropped by 84 percent between August 1996 and September 1999. ${ }^{9}$ Wisconsin, however, has no more claim to be properly representative of what is going on nationally than any other state in the union. A significant reason for its pre-eminence was the media savvy of its publicity greedy governor, Republican Tommy Thompson, who became President Bush's Secretary of Health and Human Services. Other states, however, which receive less publicity have been equally activist in trying to help welfare recipients prepare for and adjust to work. Oregon, for example, with a caseload reduction of 45 per cent, brought its welfare numbers down without Wisconsin's stringent application of punitive measures against lagging recipients. At the other end of the scale, some states have done very little in the way of setting up innovative programmes, but 'achieved' high caseload reduction over this period simply by changing eligibility criteria. Idaho, for instance, adopted a policy whereby families receiving Supplemental Security Income, such as those with disabled children, were not eligible for TANF, a move which accounts for a big chunk of the state's 90 per cent reduction in its welfare rolls.

Underlying some of the variation in practice is the formula used for the initial distribution of money from Washington to the states. Grants were allocated according to how much was being spent within each state on welfare in 1994. This meant that those states which had always spent more on their welfare population, generally - meaning those which had higher benefit levels - got more money. This was a political settlement reflecting two factors. First, the Republican majority in Congress was not prepared to increase the overall welfare bill; and second, given that the overall pie was to remain the same size, if those states with high existing welfare costs were to play ball they would not accept any reduction in their funding from the centre. This meant that there were significant differences in how much money per recipient each state received from the federal government in order to make welfare to work programmes work.

Furthermore, the path taken by each state has different ramifications for how the federal requirements impact on it. Minnesota, for instance, is one of 
the few states to include a commitment to reducing poverty in its welfare reform programme. To this end it continues to pay meaningful benefits to recipients who have moved into work which boosts the income of those in low wage jobs. The downside is that recipients are still eating into their welfare lifetime limit when they do have an alternative source of income (Nolan, 2000).

Overall, it is imperative to recognise that the politics and policy histories of the states are distinct, which has inevitably resulted in different ways of implementing the PRWORA directives. Ironically, however, since the divergence in practice means that it is difficult to identify a particular state to use as a representative case study it is perhaps better to rely on aggregate national data rather than a skewed state sample.

\section{Reducing dependency: an undebateable success?}

The most immediate evidence is the enormous percentage drop in the overall welfare rolls. Between August 1996 and September 1999 the number of families receiving welfare had dropped from 4.415 million to 2.453 million, a fall of 44 per cent (Administration for Children and Families, 2000). At the high point of AFDC use, in 1994, 5.5 per cent of the population received AFDC (US, 1998: 402). In contrast, in June 1999 only 2.5 per cent of the American population were getting TANF. For conservatives in the Rector school these figures in themselves represent success regardless of what else is happening.

Subtler champions of reform, however, are less interested in this headline figure and maintain that the most important performance indicator is that which shows that an increased number of former welfare recipients are now engaged in work. As noted above, there are problems in gauging the exact work effort of welfare recipients, but by any measure an increasing number have been active in the labour market. For example, between 1993 and 1999 there was a 50 per cent increase in the number of never married mothers, historically the least likely of all women to do paid work, who had a job (Haskins et al., 2001: 4). For critics of the old welfare system such as Mead this is crucial because it is through working that welfare recipients will best lose their 'welfare' status and become integrated into mainstream society.

A related favourite theme of those celebrating the changes is to expand upon the new-found self-respect of those who have moved from welfare to work and to emphasise how important it is for the children of welfare mothers to see that there is an alternative and more dignified route through life than cashing government cheques (Rogers, 1999). Indeed these 'empowerment' conservatives maintain that welfare recipients themselves have welcomed the pressure to reorder their lives. Most of the stories told to this effect are anecdotal, but one survey based on fifteen focus groups consisting of welfare recipients and the fathers of their children in Baltimore, Boston and Chicago, conducted in late 1996 and throughout 1997, 
found a perhaps surprising openness to some of the apparently harsher elements of the new law. While the authors noted that some respondents were 'scared and angry', they reported that, 'The majority of the participants favored time limits on welfare receipt. This was true among African Americans, Hispanics and whites and among women and men. They viewed the new provisions as providing them with the motivation to find jobs and improve their lives' (Burton et al., 1998: 5).

What supporters of the reform emphasise is the overall cocktail of measures. They acknowledge that there are some punitive elements, but insist that these are necessary. Thus an effective sanctions policy is organic to the message that work effort is a must. ${ }^{10}$ One way in which this is often framed is that welfare should be made as close as possible to the real, that is non-welfare, world. If people fail to turn up to work for no good reason then they do not get paid. Similarly, therefore, if a welfare recipient skips a designated work-related activity then they will lose some benefit. In addition the five-year lifetime limit is defended on the basis that it concentrates the mind of both recipient and the caseworker. A further feature which has emerged in many states is the policy of so-called 'diversion'. Essentially this is an effort to prevent people from signing on in the first place. Applicants are advised that they will be expected to look for work and so if they can find it, or at least some other form of income, they are better off doing this rather than eating into their welfare time. It is impossible to be accurate but it is clear that this diversion policy has played a significant role in reducing the welfare numbers. People have always left welfare for many reasons, but they would in turn always have been replaced. The current trend is that fewer and fewer leavers are replaced. Again, advocates of reform point to this as evidence that many potential welfare recipients will make the effort to look after themselves once it is made clear that long-term benefit receipt is not an option. ${ }^{11}$

Mead, and others who see increased work effort not caseload reduction as the real goal of reform, point out that the punitive measures tell only part of the story. Many states are making a constructive effort to help recipients overcome barriers to work and part of the 1996 package was an increase in federal funds given to states which had to be devoted to child care. An integral element has been an effort to change the mindset of the welfare bureaucracies; and, according to Nathan and Gais, PRWORA's stark message did penetrate state welfare offices, prompting caseworkers to take a more interventionist role rather than acting simply as clerks checking eligibility (1999).

\section{Reducing poverty: a more ambiguous view}

There are, however, those who present a more ominous picture of the consequences of reform, concentrating less on dependency and more on poverty. AFDC benefits had never been generous enough to lift families above the official poverty line, and in some states they were desperately miserly, but they had at 
least constituted a source of income for a vulnerable section of the population. Critics of reform focus on the fact that even in a time of economic prosperity the actual financial position of most poor single-parent families did not significantly improve in the late 1990s and that for a minority things appeared to get worse.

Data suggests that a substantial majority of those welfare recipients who do move into work earn below poverty line wages. A Children's Defense Fund analysis found that among people who received any welfare in 1997, and who had earnings in March 1998, 'only 28.8 per cent earned usual weekly wages above the equivalent of the three-person poverty line (about \$250 a week in 1998 dollars)'. Moreover, ' 51 per cent of recent recipients who had earnings in March 1998 had weekly wages below three-quarters of the poverty line' (Sherman et al., 1998: 9). A Center on Budget and Policy Priorities survey confirmed that 'Studies that measure parents' earnings over three-month periods find earnings levels well below the poverty line' (Parrott, 1998: 10). Many of these families will be eligible for the Earned Income Tax Credit and Food Stamps and, depending on their state's policy, may continue to receive some TANF benefits. Nevertheless, even if all of these are factored in (and the extra costs involved in working are ruled out), moving into work will likely make former recipients better off only marginally, with the strong likelihood that family income will remain below the poverty line (Jencks and Swingle, 2000: 38 ).

Furthermore, it is unclear just how much qualitative improvement there has been in the lives of those recipients who have moved into work. Many struggle to juggle complex home lives with the demands of the workplace (Heymann, 2000), especially as most welfare recipients are low skilled and 'the jobs available to low-skilled women tend to pay low wages, experience high turnover, and offer few fringe benefits or opportunities for advancement to higher wage positions' (Bloom, 1997: 17). For example, one pre-PRWORA welfare-to-work experiment in California, deemed a success illustrating the viability of reform, found that of those welfare recipients who moved into work only 28.8 per cent found jobs with paid sick days, only 34.1 per cent with paid vacation days and only 27.5 per cent had health benefits attached (Riccio et al., 1994: 170). ${ }^{12}$ Overall, while it may well be true that earning one's income can be a source of self-respect for many on welfare this is only a solution to one of life's many problems (DeParle, 1999).

There is also concern about those no longer on welfare but not working. This constitutes a significant group of people whose fate is unclear (Sherman et al., 1998: 8). Some will have moved in with relatives or boyfriends, but others seem to have just disappeared. Where there is data available there is evidence of an increase in levels of extreme poverty, partially, at least, caused by a reduction in welfare payments. A CBPP report found that the worst off 20 percent of single-parent families suffered a 7 per cent decline in disposable income between 1995 and 1997, leaving them with an average of $\$ 8,047$. According to the authors, 
'Almost 80 per cent of the decline... resulted from losses of means-tested benefits' (Primus et al., 1999: 10). The same report also notes that in 1995, 3.2 million children were removed from poverty by means-tested benefits, but that in 1997 this had dropped 2.4 million (p. 23). ${ }^{13}$ One problem is that welfare caseload decline has outstripped the decline in poverty. That is, in 1993, 57 percent of poor children were in families receiving AFDC but in 1998 only 47 per cent were in families receiving TANF; and, while child poverty dropped by 5.3 per cent between 1995 and 1997 the child welfare caseload decline was 16.5 per cent over the same period (Primus, 1999).

Critics also worry that some of the features encouraged by reform advocates are at best double-edged swords. For example, supporters claim that diversion shows that people will make more of an effort from the start if they are encouraged to do so. In reality, though, very little is known about who the 'diverted' are and what subsequently happens to them once their initial application for TANF is delayed. There is certainly evidence that a significant number do not realise that they are still eligible for other benefits such as Food Stamps and Medicaid even if they cannot immediately claim TANF (Meyers, 2000). One implication is that diversion roots out those who were claiming welfare while getting income from undeclared work; yet, while there is evidence that many welfare mothers did technically defraud the state this was often the only way that they could make ends meet (Edin and Lein, 1997). Another worry surrounds the use of sanctions. Data on families likely to be sanctioned is limited, but some early indicators suggest that those adults penalised 'were more likely to have dropped out of high school ... or to have reported ... transportation, child care, or health difficulties' than other TANF family heads (US, 2000: 5).

\section{The jury is still out}

There are a number of areas where the jury is still out and more evidence is needed before any sensible judgements can be reached. It is too early, for example, to say whether the reform will make a difference to family structures (Deacon, 2001: 7); and even if evidence emerges that more potentially poor single mothers are living with partners it would still need to be ascertained that this was a plus for their general welfare. One lurking question is what the long-term affects of economic downturn and in particular a rise in unemployment will be (Pavetti, 1998). Implicit in the setting of time limits is the assumption that there are sufficient jobs available for welfare recipients to move successfully into the labour market. This remains disputed (Mead, 1992; Wilson, 1996; Lerman et al., 1999), but the sustained period of economic growth in the late 1990 did mean that the initial circumstances were as favourable as possible for implementing a work enforcement regime. Whether the jobs will disappear in the event of a long downturn cannot be simply predicted. Low-wage work does tend to be 
particularly sensitive to economic fluctuations, but the existing models studying the affects of recession on welfare rolls were developed in the pre-PRWORA context and do not take into account the unprecedented number of welfare leavers since the mid-1990s.

A related question is whether the 'Work First' philosophy which most states have written into their programmes, which basically says that any job is preferable to education and training, will be to the long-term advantage of those making the welfare to work transition. The rationale is that work discipline is the priority (combined with the feeling that many welfare clients have negative attitudes towards education). The potential downside is that people will remain stuck in low-wage jobs because they have not developed the skills to progress.

It is also uncertain how the five-year maximum will be applied. Will states blink and find ways of continuing to subsidise poor families? Indeed it is far from clear that states have the bureaucratic capacity to track quite how long people have been on welfare. A possible scenario is the rather random application of PRWORA's regulations with the potential danger that if fewer people are left stranded than the law's critics have predicted then those that are cut off will be little noticed.

\section{Conclusion: bringing values back in}

Clearly then, there is already much contrasting evidence as to the success of the reform with much yet to be revealed. Indeed some conservatives have acknowledged that if the real goal of reform 'is less dysfunctional behaviour among parents and better outcomes for children' then 'We may need a generation to find out' what the impact of PRWORA has been (Besharov and Germanis, 2001: 79). Most commentators, however, do not have such patience and as things stand, those who advocated the reform are championing the preliminary results and opponents, while still expressing their concerns, are somewhat on the back foot. When sifting through the evidence, however, it is important not to miss the wood for the trees. That is, it is necessary to step away a little from the effort to crunch the raw data and take the debate back into the realm of ideology and more specifically to citizenship. Clearly policy should be based on good practice, but the analysis of what exactly constitutes good practice is in many cases unresolved. Sometimes this is because of genuinely different methodological approaches and the difficulty of obtaining reliable data sets. More fundamentally, however, it also reflects the fact that the analysts, for all their statements of objectivity, are trying to prove different things - or at least highlight different perspectives, which in turn reflects their different value judgements. It is pretty easy to agree that people should be encouraged into the workforce, and that if barriers to employment can be identified, government should help to overcome them; but should government compel work in return for benefits and say that ultimately 
it is not responsible for the economic fate of its citizens? PRWORA suggests that the American government has come to the conclusion that it should and fundamentally this judgement is not based on accumulated research evidence but is a statement of political and social values. Work is, in effect, a prerequisite of citizenship, at least for the welfare poor.

\section{Notes}

1 The author would like to thank the Nuffield Foundation for its generous support in helping fund the research for this article.

2 Some see that as a move back to 'Poor Law' style ideology (Handler and Hasenfeld, 1997; Heron and Dwyer, 1999).

3 In 1996, 4,553,000 families received AFDC. Of these, 302,00o were covered by the AFDC-UP programme where needy two-parent families could claim benefit if the principal wage earner was unemployed but had a recent work history (US, 1998: 402).

4 Many states were already experimenting under so-called 'waivers' schemes (Friedlander and Burtless, 1995; Norris and Thompson, 1995). In the mid-199os there was a wider movement to devolve key elements of domestic policy down to the states although, AFDC apart, this effort largely failed (see Weaver, 1996).

5 TANF recipients will also likely be eligible for Food Stamps and various child nutrition programmes as well as Medicaid.

6 This percentage was not based on social science research but was a compromise political number. States can also provide aid to recipients beyond five years at their own expense.

7 In theory, AFDC was not an unqualified entitlement as the Work Incentive Program amendments of 1971 and the Family Support Act of 1988 had attached work requirements to the benefit. These, however, had only been applied to a minority of recipients (see Berkowitz, 1991: 133-6 on WIN; and King, 1991, on the FSA). As it was, in the early 1960s about 33 per cent of families applying for welfare were successful. By 1971 around 90 per cent were (Katz, 1989: 106).

8 David Ellwood, working in the Department of Health and Human Services, was a key figure in drawing up the Clinton bill. He described himself as very satisfied with its content. Interview with author, April 1999.

9 The data for Wisconsin and for all states mentioned in this section are from Administration for Children and Families (2000).

10 Rector and Youssef argue that caseload decline is related to each state's application of sanctions. The tougher the sanction regime then the sharper the decline. In contrast, they argue, there is no direct correlation between state unemployment rates and caseload change (1999).

11 For a discussion of diversion techniques, see Maloy et al. (1998).

12 This needs to be understood in an American context where many workers, who have never been on welfare, are employed on these conditions (Levitan et al., 1993; Schwarz, 1997), and the effort to push welfare clients into work is not intended to put them in a position where they are better off than the already working poor or near-poor.

13 'Means-tested' here refers to AFDC/TANF, Food Stamps, Supplemental Security Income, school lunches and housing assistance.

\section{Acknowledgements}

The author would like to thank the Nuffield Foundation for the financial support which made it possible to conduct the research for this article. 


\section{References}

Administration for Children and Families (2000), 'Change in TANF Caseloads Since the Enactment of New Welfare Law', US Department of Health and Human Services, 6 June.

Bane, M. J. (1997), 'Welfare as We Might Know it', The American Prospect, 30: 47-55.

Bane, M. J. and D. Ellwood (1994), Welfare Realities: From Rhetoric to Reform, Cambridge, MA: Harvard University Press.

Berkowitz, E. D. (1991), America's Welfare State: from Roosevelt to Reagan, Baltimore: John Hopkins University Press.

Besharov, D. and P. Germanis (2001), 'Welfare Reform: Four Years Later', in D. Besharov, P. Germanis, J. Hein, D. Jonas and A. Sherman, Ending Dependency: Lessons From Welfare Reform in the USA, London: Civitas.

Bloom, D. (1997), After AFDC: Welfare-to-Work Challenges for States, Manpower Demonstration Research Corporation.

Burton, L., A. Cherlin, J. Francis, R. Jarrett, J. Quane, C. Williams and M. Cook (1998), What Welfare Recipients and the Fathers of Their Children Are Saying about Welfare Reform, Baltimore: John Hopkins University Press.

Deacon, A. (2000), 'Learning from the US? The influence of American ideas upon 'new labour' thinking on welfare reform', Policy and Politics, 28: 1, 5-18.

Deacon, A. (2001), 'Introduction: The Realities of Welfare Reform: Some Home Truths From the USA?', in D. Besharov, P. Germanis, J. Hein, D. Jonas and A. Sherman, Ending Dependency: Lessons From Welfare Reform in the USA, London: Civitas.

DeParle, J. (1999), 'Bold Effort Leaves Much Unchanged for the Poor', New York Times, 30 December.

Edin, K. and L. Lein (1997), Making Ends Meet: How Single Mothers Survive Welfare and LowWage Work, New York: Russell Sage Foundation.

Ellwood, D. (1988), Poor Support: Poverty in the American Family, New York: Basic Books.

Ellwood, D. (1996), 'Welfare Reform As I Knew It', The American Prospect, 26: 22-9.

Friedlander, D. and G. Burtless (1995), Five Years After: The Long-Term Effects of Welfare-to-Work Programs, New York: Russell Sage Foundation.

Gilder, G. (1981), Wealth and Poverty, New York: Basic Books.

Gordon, L. (1994), Pitied But Not Entitled: Single Mothers and the History of Welfare, New York: The Free Press.

Handler, J. F. and Y. Hasenfeld (1997), We the Poor People: Work, Poverty and Welfare, New Haven: Yale University Press.

Haskins, R., I. Sawhill, and K. Weaver (2001), Welfare Reform: An Overview of Effects to Date, Washington, DC: The Brookings Institution.

Heron, E. and P. Dwyer (1999), 'Doing the Right Thing: Labour's Attempt to Forge a New Welfare Deal Between the Individual and the State', Social Policy and Administration, 33: $1,91-104$.

Heymann, J. (2000), The Widening Gap: Why America's Working Families Are in Jeopardy and What Can Be Done About It, New York: Basic Books.

Jencks, C. and J. Swingle. (2000), 'Without a Net: Whom the New Welfare Law Helps and Hurts', The American Prospect, 11: 4, 37-41.

Katz, M. (1989), The Undeserving Poor: From War on Poverty to War on Welfare, New York: Pantheon Books.

King, D. (1991), 'Citizenship as Obligation in the United States: Title II of the Family Support Act of 1988', in U. Vogel and M. Moran (eds.), The Frontiers of Citizenship, London: Macmillan, $1-31$.

King, D. and M. Wickham-Jones (1999), 'Clinton and Blair: The Democratic (Party) Origins of Welfare to Work', Political Quarterly, 70: 1-13.

Lerman, R., P. Loprest, and C. Ratcliffe (1999), How Well Can Urban Labor Markets Absorb Welfare Recipients?, Washington, DC: The Urban Institute.

Levitan, S., G. Gallo, and I. Shapiro (1993), Working But Poor: America's Contradiction, Baltimore: John Hopkins University Press. 
Maloy, K. A., L. Pavetti, P. Shin, J. Darnell and L. Scarpulla-Nolan (1998), State Approaches to Diversion Programs and Activities Under Welfare Reform: An Interim Report of the Findings of the First Phase of the Research, The George Washington Center for Health Policy Research.

Marshall, T. H. (1981), The Right to Welfare and Other Essays, London: Heinemann Educational Books.

Mead, L. (1992), The New Politics of Poverty: The Nonworking Poor in America, New York: Basic Books.

Mead, L. (ed.) (1997a), The New Paternalism, Washington, DC: Brookings Books.

Mead, L. (1997b), 'Citizenship and Social Policy: T. H. Marshall and Poverty', in E. F. Paul, F. D. Miller and J. Paul (eds.), The Welfare State, Cambridge University Press, 197-230.

Mead, L. (1997c), 'From Welfare to Work: Lessons From America', in A. Deacon (ed.), From Welfare to Work: Lessons From America, London: Institute of Economic Affairs.

Meyers, M. K. (2000), 'How Welfare Offices Undermine Welfare Reform', The American Prospect, 11: $15,41-5$.

Murray, C. (1984), Losing Ground: American Social Policy, 1950-1980, New York: Basic Books.

Nathan, R. and T. Gais (1999), Implementing the Personal Responsibility Act of 1996: A First Look, New York: The Nelson A. Rockefeller Institute of Government.

Nolan, C. (2000), 'Minnesota's Welfare Program Shows Dramatic Results', Stateline.org, 31 May, http://www.stateline.prg/story.cfm?stroyid $=79854$.

Norris, D. and L. Thompson (eds.) (1995), The Politics of Welfare Reform, Thousand Oaks: Sage Publications.

Parrott, S. (1998), Welfare Recipients Who Find Jobs: What Do We Know About Their Employment and Earnings?, Washington, DC: Center on Budget and Policy Priorities.

Pavetti, L. (1998), 'What Will the States Do When Jobs are Not Plentiful? Policy and Implementation Challenges', Background Papers, Welfare Reform and the Macroeconomy Conference, Northwestern University/University of Chicago: Joint Center for Poverty Research.

Primus, W. (1999), 'Block Grants and Welfare Reform', presentation to the Committee on Ways and Means Welfare Seminar Series, 19 March, Washington, DC.

Primus, W., L. Rawlings, K. Larin, and K. Porter (1999), The Initial Impacts of Welfare Reform on the Incomes of Single-Mother Families, Washington, DC: Center on Budget and Policy Priorities.

Rector R. (1992), 'Requiem for the War on Poverty: Rethinking Welfare After the Los Angeles Riots', Policy Review (Summer), 40-6.

Rector, R. (1996), 'God and the Underclass', National Review, 15 July, 30-3.

Rector R. and S. Yousef (1999), Welfare Reform and Caseload Decline, Washington, DC: Heritage Foundation.

Riccio, J., D. Friedlander, and S. Freedman (1994), GAIN: Benefits, Costs, and Three-Year Impacts of a Welfare-to-Work Program, Manpower Demonstration Research Corporation.

Rogers, J. J. (1999), 'Statement of J. Jean Rogers, Administrator Wisconsin Department of Workforce Development, Madison, Wisconsin', Testimony Before the Subcommittee on Human Resources of the House Committee on Ways and Means, Hearings on the Effects of Welfare Reform, 27 May.

Sawhill, I. (1995), 'Distinguished Lecture on Economics in Government; The Economist vs. Madmen in Authority', Journal of Economic Perspectives, 9: 3, 3-13.

Schwarz, J. (1997), Illusions of Opportunity: The American Dream in Question, New York: W. W. Norton and Company.

Sherman, A., C. Amey, B. Ebb. Duffield, and D. Weinstein (1998), Welfare to What: Early Findings on Family Hardship and Well-Being, Washington, DC: Children's Defense Fund/National Coalition for the Homeless.

Shklar, J. (1991), American Citizenship: The Quest for Inclusion, Cambridge, MA: Harvard University Press. 
Teles, S. (1996), Whose Welfare: AFDC and Elite Politics, University of Kansas Press.

US (1994), Committee on Ways and Means, US House of Representatives, 1994 Green Book: Background Material and Data on Programs within the Jurisdiction of the Committee on Ways and Means, Washington, DC: US Government Printing Office.

US (1996), Committee on Ways and Means, US House of Representatives, 1996 Green Book: Background Material and Data on Programs within the Jurisdiction of the Committee on Ways and Means, Washington, DC: US Government Printing Office.

US (1998), Committee on Ways and Means, US House of Representatives, 1998 Green Book: Background Material and Data on Programs within the Jurisdiction of the Committee on Ways and Means, Washington, DC: US Government Printing Office.

US (2000), United States General Accounting Office, Welfare Reform: State Sanction Policies and Number of Families Affected, Washington, DC.

US (2001), United States General Accounting Office, Welfare Reform: Moving Hard-to-Employ Recipients Into the Workforce, Washington, DC.

Waddan, A. (1998), 'A Liberal in Wolf's Clothing: Nixon's Family Assistance Plan in the Light of 199os Welfare Reform', Journal of American Studies, 32: 2, 203-18.

Weaver, R. K. (1996), 'Deficits and Devolution in the 104th Congress', Publius, 26: 3, 45-86.

Weaver, R. K. (2000), Ending Welfare as We Know It, Washington, DC: Brookings Institution.

Weaver, R. K., R. Y. Shapiro and L. R. Jacobs (1995), 'The Polls-Trends: Welfare', Public Opinion Quarterly, 59: 606-27.

Wilson, W. J. (1996), When Work Disappears: the World of the New Urban Poor, New York: Vintage Books. 